\title{
Dental Students', Alumni, and Dentists' Perspectives on Leadership: Impact of the Scholars Program in Dental Leadership
}

\author{
Audrey L. Niemchick, BS; Jessica Delgado, DDS; Russell S. Taichman, DMD, DMSc; \\ Marita R. Inglehart, Dr phil habil
}

Abstract: In 2006, the Scholars Program in Dental Leadership (SPDL) was created at the University of Michigan School of Dentistry with the aim of preparing dental students to take on leadership roles in their profession and communities. The aims of this quantitative study were to investigate how SPDL alumni and current participants evaluated this program; to assess whether SPDL alumni evaluated their leadership-related educational experiences, leadership perceptions, and attitudes towards leadership activities in dentistry more positively than did non-SPDL dental students and general dentists; and to explore if leadership-related educational/clinical experiences were correlated with these constructs. Participants were 218 of 431 dental students across all four years (response rate 51\%), 32 of whom were participants in the SPDL; 32 of 53 SPDL alumni (response rate 60\%); and 595 of 3,000 general dentists invited to participate (response rate 20\%). Both current and past SPDL participants evaluated the program on average positively ( 3.75 and 3.92, respectively, on a five-point scale). Non-SPDL students and alumni evaluated leadershiprelated educational experiences more positively than did the dentists (3.65/3.61 vs. 2.49; $\mathrm{p}<0.001)$. Their evaluations of different indicators of dental leadership differed as well. Students and alumni evaluated being recognized (4.40/4.60 vs. 4.20; $\mathrm{p}<0.001)$, making a contribution to the community $(4.04 / 4.40$ vs. $3.81 ; \mathrm{p}<0.001)$, and views on practice efficiency $(4.61 / 4.53 \mathrm{vs}$. 4.36 ; $\mathrm{p}<0.001)$ more positively than did the general dentists. The SPDL alumni had more positive evaluations of organized dentistry (4.17 vs. 3.77/3.71; $\mathrm{p}=0.045)$ and academia (3.97 vs. 3.48/3.45; $\mathrm{p}=0.01)$ than did the students and general dentists. Educational/ clinical experiences were positively correlated with most leadership-related constructs. These results showed that the SPDL positively affected alumni perceptions of leadership indicators and attitudes.

\begin{abstract}
Ms. Niemchick is a dental student, School of Dentistry, University of Michigan; Dr. Delgado is a resident, Orthodontic Graduate Program, Dental School, University of Detroit Mercy; Dr. Taichman is Major M. Ash Collegiate Professor, Associate Dean for Research, and Professor of Dentistry, Department of Periodontics and Oral Medicine, School of Dentistry, University of Michigan; and Dr. Inglehart is Professor of Dentistry, Department of Periodontology and Oral Medicine, School of Dentistry, and Adjunct Professor, Department of Psychology, College of Literature, Science of Arts, University of Michigan. Direct correspondence to Dr. Marita R. Inglehart, Department of Periodontics and Oral Medicine, School of Dentistry, University of Michigan, 1011 N. University Ave., Ann Arbor, MI 48109-1078; 734-763-8073; mri@umich.edu.
\end{abstract}

Keywords: dental education, dental students, dentists, alumni, leadership, leadership training, community engagement

Submitted for publication 4/17/16; accepted 6/30/16

$\mathrm{M}$ odern health care and health care systems have been experiencing dramatic changes over the past years. As technology, patient expectations, policy, and legislatures are evolving, dentistry must respond to these changes. ${ }^{1}$ If dental professionals do not take the lead in addressing these challenges, policymakers not educated in the field are likely to take over. ${ }^{2,3}$ In a recent survey of general dentists who were members of the American Dental Association (ADA), between one-third and two-thirds of the respondents did not agree that their predoctoral education had prepared them well for leadershiprelated activities in their practice or community or at the state and national levels. ${ }^{4}$ It is therefore critically important to better educate the next generation of dentists about taking on leadership roles. Victoroff et al. found that such an approach would likely be welcomed by dental students: in their study, participating students had positive attitudes about dental leadership, and about two-thirds expressed interest in participating in leadership-related educational programs. ${ }^{5}$ However, leaders of some programs without leadership training have argued that only students and faculty explicitly interested in leadership positions should receive leadership training and noted that leadership education is not part of their mission statement. ${ }^{6}$ The same study found that, when leadership training was incorporated, more than half of the programs focused on preparing students to become good leaders of their dental teams. While this topic is important, additional leadership-related aspects also need to be addressed to ensure that general dentists do not merely perceive patient-staff aspects of their practices as being important indicators of leadership. ${ }^{7}$ 
Previous leadership-related research in dental education has offered both theoretical and strategic considerations/recommendations. ${ }^{8-14}$ In addition, empirical studies have assessed the benefits of leadership-related education for predoctoral dental students ${ }^{15,16}$ and/or postdoctoral students ${ }^{17,18}$ and for dental educators. ${ }^{19}$ While there are certainly barriers and challenges (such as cost and a large time commitment for faculty ${ }^{20}$ as well as curriculum crowding) to incorporating leadership programs into predoctoral dental education, it is nevertheless important to consider how to best integrate more leadership-related education into dental curricula to prepare future professionals for taking on a greater role as leaders of and advocates for their own profession.

In 2006, a leadership-related program, the Scholars Program in Dental Leadership (SPDL), was instituted at the University of Michigan to explore how to increase leadership education in this dental school. SPDL's mission has been to empower dental students to foster changes and become leaders in the field of dentistry by bringing together a diverse group of talented students and helping them develop leadership skills. ${ }^{21}$ Some key features of this program are to offer participating students opportunities to interact with faculty and administrators in leadership positions, to challenge them to get actively involved in their communities, and to participate in meetings with community leaders. SPDL also offers information about career pathways students may not have previously considered, such as in academia.

After a decade of SPDL activities, we sought to evaluate some of its outcomes. The aims of this study were to investigate how SPDL alumni and current SPDL participants evaluated the program; to assess whether SPDL alumni evaluated their leadershiprelated educational experiences, leadership perceptions, and attitudes towards leadership activities in dentistry more positively than did dental students and general dentists; and to explore if leadership-related educational/clinical experiences were correlated with these leadership-related constructs.

\section{Methods}

This study was determined to be exempt from oversight by the Institutional Review Board for the Behavioral and Health Sciences at the University of Michigan (HUM\# HUM00070508; Amendment \#00055813). Participants were current dental students and SPDL alumni of the school and a national sample of practicing dentists. Data were collected from the practitioners in 2013, the SPDL alumni in 2014-15, and the students in 2015.

The SPDL is an extracurricular program focused on leadership development for dental and dental hygiene students. Students are encouraged to apply to the program before their first year of school, although upper class students are frequently admitted. The application requires letters of recommendation and essays. Students are selected based on their previous leadership experience, interest and desire to be a leader, general communication skills, and willingness to take on the additional workload. ${ }^{21}$ The program consists of a yearly kick-off event held in the summer, monthly leadership training meetings, often with guest speakers, a capstone project, and student-run committees. ${ }^{1,21}$ Students have the opportunity to influence which program activities are included each year and have numerous opportunities to interact with faculty members one-on-one or in small groups. ${ }^{21}$ The students are able to define their own involvement with the SPDL.

All 431 dental students in all four years and 53 alumni who had taken part in the SPDL were invited to participate in this study. Most of the dental students were informed about the study at the end of regularly scheduled classes and received a paper and pencil survey at that time. After they had responded, they returned the survey anonymously to the research team. The SPDL alumni were contacted with a recruitment email by the director of the SPDL (author RST) that explained his interest in following up and understanding whether the SPDL had had an effect on their professional lives. The email contained a web link to the survey that could be answered anonymously.

The national sample of dentists was recruited with a recruitment letter included in a postal mailing. This letter explained the interest in understanding general dentists' thoughts about leadership in dentistry. Surveys were mailed to 3,000 randomly selected ADA members. More details about this part of the survey can be found in two previous publications. ${ }^{4,7}$

The survey consisted of four general sections plus SPDL-specific questions for the SPDL alumni and current SPDL participants. Section 1 inquired about the respondents' demographic and educational characteristics. The SPDL-specific questions for former and current program participants followed after Section 1. Section 2 consisted of 12 questions concerning the quality of the respondents' leadershiprelated education. A factor analysis (extraction method: Principal Component Analysis; rotation method: 
Varimax with Kaiser Normalization) resulted in a three-factor solution. The six questions concerning the respondents' evaluations of their predoctoral leadership-related education loaded on a first factor; three items inquiring how well their clinical experiences had prepared them for their dental practice activities loaded on a second factor; and three items concerning how well their clinical experiences had prepared them for leadership roles loaded on a third factor. The answer scale for these items ranged from $1=$ not at all well to $5=$ very well. Three indices were computed by averaging the responses to the items loading on each factor. The Cronbach's alpha coefficients showed that the inter-item consistency of these three subscales was very good $(0.930,0.849$, and 0.908 , respectively).

Section 3 consisted of 20 five-point rating scale questions (with response options from $1=$ not at all well to $5=$ very well) concerning how well various activities reflect leadership in dentistry. A factor analysis (extraction method: Principal Component Analysis; rotation method: Varimax with Kaiser Normalization) of these 20 items resulted in a five-factor solution. Five indices were computed by averaging the responses to the questions that loaded on each of the five factors. The inter-item consistency coefficients showed that these five subscales had good to very good reliability, with Cronbach's alphas ranging from 0.735 to 0.894 .

Section 4 assessed the respondents' leadershiprelated attitudes with eight five-point rating scale questions. A factor analysis (extraction method: Principal Component Analysis; rotation method: Varimax with Kaiser Normalization) with these eight items resulted in a two-factor solution. Two indices were computed by averaging responses to the questions that loaded on each of the two factors. The inter-item consistency of the first subscale was very good (Cronbach's alpha $=0.821$ ), and the reliability of the second subscale was acceptable (Cronbach's alpha $=0.606$ ).

The paper and pencil survey responses were entered into an SPSS Statistics for Windows, Version 22 data file (IBM Corp., Armonk, NY, USA). The web-based data were downloaded from the UM lessons website at the University of Michigan as an Excel file and imported into SPSS. After the data had been prepared for analysis, descriptive statistics such as frequency distributions, percentages, means, and standard deviations were computed to provide an overview of the responses. Independent sample t-tests were used to compare the average responses of cur- rent and past SPDL participants, and a chi-square test was used to compare the frequencies of responses to the question of whether the program had helped them recognize career pathways they had not considered before. Univariate analyses of variance were used to compare the mean responses of the current dental students, the SPDL alumni, and the general dentists. Factor analyses were used to analyze the underlying factor structure of the responses. Cronbach's alpha reliability coefficients were computed to evaluate if the inter-item consistency of the items loading on each factor justified creating indices. The indices were computed by averaging the responses to the items loading on each factor. Pearson correlation coefficients were computed to determine the relationships between educational indices and leadershiprelated indices. Given the number of comparisons analyzed and of Pearson correlation coefficients determined, Bonferroni corrections were applied by setting $p<0.01$ as the level of significance.

\section{Results}

Of the 431 dental students invited to participate, 218 returned the paper survey (response rate 51\%); 32 of them were participants in the SPDL. In addition, 32 of the 53 SPDL alumni (response rate $60 \%$ ) and 595 of the 3,000 general dentists invited to participate (response rate 20\%) completed the survey online.

The responding dental students were more likely to be in the earlier years of the program (Table 1). Most of them were male (59\%) and European American $(71 \%)$; their average age was 25 years (range: 21-35 years). The SPDL alumni had participated in the program before they graduated between 2006 and 2013. Among these alumni, 56\% were female, and $75 \%$ were European American; they were on average about 30 years old (range: $27-36$ years). The national sample of general dentists had graduated from dental school between 1964 and 2013. The majority of them were male (77\%) and European American (85\%), and their average age was 51 years (range: 27-72).

The first objective was to explore how the current and past SPDL participants perceived the benefits of the SPDL. Both groups were rather positive about the SPDL overall (on the five-point scale with $5=$ most positive: 3.69 vs. $3.94 ; \mathrm{p}=0.246$ ) and its components such as involvement with other students ( 3.66 vs. $3.97 ; p=0.120$ ), the Capstone project ( 4.00 vs. $3.65 ; p=0.156)$, the kick-off event ( 3.28 vs. $3.63 ; \mathrm{p}=0.256$ ), and the ability to determine their 


\begin{tabular}{|c|c|c|c|c|}
\hline Characteristic & Dental Students & SPDL Alumni & National Dentists & $\mathrm{p}$-value \\
\hline Number of responses & 218 & 32 & 595 & \\
\hline Response rate & $51 \%$ & $60 \%$ & $20 \%$ & \\
\hline Current SPDL students & $32(15 \%)$ & & & \\
\hline \multicolumn{5}{|l|}{ Year in program } \\
\hline D1 & $103(47 \%)$ & & & \\
\hline D2 & $56(26 \%)$ & & & \\
\hline D3 & $47(22 \%)$ & & & \\
\hline D4 & $12(5 \%)$ & & & \\
\hline \multicolumn{5}{|l|}{ Graduation year } \\
\hline Mean (SD) & & $2010(1.43)$ & $1988(11.03)$ & $<0.001$ \\
\hline Range & & 2006-13 & $1964-2013$ & \\
\hline \multicolumn{5}{|l|}{ Gender } \\
\hline Male & $128(59 \%)$ & $14(44 \%)$ & $458(77 \%)$ & $<0.001$ \\
\hline Female & $90(41 \%)$ & $18(56 \%)$ & $135(23 \%)$ & \\
\hline \multicolumn{5}{|l|}{ Age } \\
\hline Mean (SD) & $25(3.04)$ & $30(2.32)$ & $51(10.75)$ & $<0.001$ \\
\hline Range & $21-35$ & $27-36$ & $27-72$ & \\
\hline \multicolumn{5}{|l|}{ Race/ethnicity } \\
\hline European American & $152(71 \%)$ & $24(75 \%)$ & $493(85 \%)$ & $<0.001$ \\
\hline African American & $4(2 \%)$ & $1(3 \%)$ & $13(2 \%)$ & \\
\hline Asian American & $40(18 \%)$ & $5(16 \%)$ & $50(9 \%)$ & \\
\hline Hispanic/Latino & 0 & 0 & $15(3 \%)$ & \\
\hline American Indian & 0 & 0 & $1(0.2 \%)$ & \\
\hline Arab American & $11(5 \%)$ & $1(3 \%)$ & $2(0.3 \%)$ & \\
\hline $\mathrm{Bi} /$ multiracial & $8(4 \%)$ & 0 & $5(0.9 \%)$ & \\
\hline Other & 0 & $1(3 \%)$ & $2(0.3 \%)$ & \\
\hline
\end{tabular}

own involvement with the program (4.21 vs. 4.38 ; $\mathrm{p}=0.419$ ) (Table 2 ). The only significant difference in their responses was that the SPDL alumni valued the monthly leadership training more positively than did the current SPDL students (4.13 vs. 3.34; $\mathrm{p}=0.003$ ).

When asked if the SPDL helped them recognize career pathways they had not considered before, about three out of four current (75\%) and past (72\%) SPDL participants agreed that the program had done so. In addition, the survey asked how much the respondents would like to see additional components in the program. Both groups were very positive about participating in public speaking workshops (4.03 vs. $4.22 ; \mathrm{p}=0.477)$ and attending a local dental society's leadership institute ( 4.20 vs. $4.31 ; \mathrm{p}=0.597)$. They also liked the idea of having a dinner with the dean (3.69 vs. 3.97; $p=0.352$ ). However, the question about reading a book related to leadership received a more neutral evaluation ( 2.93 vs. $3.38 ; \mathrm{p}=0.243$ ).

In addition to asking current and past SPDL participants about their evaluations of the SPDL, the second objective was to assess whether the SPDL alumni were more positive in their evaluation of their educational experiences and leadership-related responses than the dental students in general and the general dentists. All respondents answered 12 questions concerning how well their predoctoral education and clinical experiences prepared them for leadership-related tasks. The current students and the SPDL alumni evaluated their predoctoral leadership education consistently more positively than did the dentists in the national sample (Table 3 ). When the effects of their clinical experiences on preparing them for dental practice were assessed, the data showed that the three groups did not differ in how well they thought their clinical experiences had prepared them to run an effective practice and to be a leader in their practice setting. However, the SPDL alumni had the most positive responses concerning the degree to which their clinical skills had prepared them for interactions and consultations with colleagues in other practices. A comparison of the three groups' mean 
Table 2. Percentages of responses concerning benefits of SPDL components, by percentage of responding current SPDL students $(\mathrm{N}=32)$ and past SPDL students $(\mathrm{N}=32)$

\begin{tabular}{|c|c|c|c|c|c|c|c|c|}
\hline Component & Group & 1 & 2 & 3 & 4 & 5 & Mean & $\mathrm{p}$-value \\
\hline SPDL program overall & $\begin{array}{l}\text { Current } \\
\text { Past }\end{array}$ & $\begin{array}{l}0 \\
0\end{array}$ & $\begin{array}{l}7 \% \\
6 \%\end{array}$ & $\begin{array}{l}31 \% \\
19 \%\end{array}$ & $\begin{array}{l}48 \% \\
50 \%\end{array}$ & $\begin{array}{l}14 \% \\
25 \%\end{array}$ & $\begin{array}{l}3.69 \\
3.94\end{array}$ & 0.246 \\
\hline Involvement with other students in SPDL & $\begin{array}{l}\text { Current } \\
\text { Past }\end{array}$ & $\begin{array}{l}0 \\
0\end{array}$ & $\begin{array}{l}3 \% \\
3 \%\end{array}$ & $\begin{array}{l}41 \% \\
22 \%\end{array}$ & $\begin{array}{l}41 \% \\
50 \%\end{array}$ & $\begin{array}{l}14 \% \\
25 \%\end{array}$ & $\begin{array}{l}3.66 \\
3.97\end{array}$ & 0.120 \\
\hline Capstone project & $\begin{array}{l}\text { Current } \\
\text { Past }\end{array}$ & $\begin{array}{c}0 \\
3 \%\end{array}$ & $\begin{array}{c}0 \\
7 \%\end{array}$ & $\begin{array}{l}33 \% \\
36 \%\end{array}$ & $\begin{array}{l}33 \% \\
32 \%\end{array}$ & $\begin{array}{l}33 \% \\
23 \%\end{array}$ & $\begin{array}{l}4.00 \\
3.65\end{array}$ & 0.156 \\
\hline Monthly leadership training meetings & $\begin{array}{l}\text { Current } \\
\text { Past }\end{array}$ & $\begin{array}{l}7 \% \\
0\end{array}$ & $\begin{array}{c}17 \% \\
6 \%\end{array}$ & $\begin{array}{l}21 \% \\
13 \%\end{array}$ & $\begin{array}{l}45 \% \\
44 \%\end{array}$ & $\begin{array}{l}10 \% \\
38 \%\end{array}$ & $\begin{array}{l}3.34 \\
4.13\end{array}$ & 0.003 \\
\hline Yearly kick-off events & $\begin{array}{l}\text { Current } \\
\text { Past }\end{array}$ & $\begin{array}{c}10 \% \\
6 \%\end{array}$ & $\begin{array}{l}7 \% \\
16 \%\end{array}$ & $\begin{array}{l}35 \% \\
22 \%\end{array}$ & $\begin{array}{l}41 \% \\
22 \%\end{array}$ & $\begin{array}{l}7 \% \\
34 \%\end{array}$ & $\begin{array}{l}3.28 \\
3.63\end{array}$ & 0.256 \\
\hline Define own involvement with program & $\begin{array}{l}\text { Current } \\
\text { Past }\end{array}$ & $\begin{array}{l}0 \\
0\end{array}$ & $\begin{array}{c}3 \% \\
0\end{array}$ & $\begin{array}{l}17 \% \\
16 \%\end{array}$ & $\begin{array}{l}35 \% \\
31 \%\end{array}$ & $\begin{array}{l}45 \% \\
53 \%\end{array}$ & $\begin{array}{l}4.21 \\
4.38\end{array}$ & 0.419 \\
\hline Index: average SPDL preparation & $\begin{array}{l}\text { Current } \\
\text { Past }\end{array}$ & & & & & & $\begin{array}{l}3.75 \\
3.92\end{array}$ & 0.307 \\
\hline New career pathways recognized: YES & $\begin{array}{l}\text { Current } \\
\text { Past }\end{array}$ & $\begin{array}{l}75 \% \\
72 \%\end{array}$ & & & & & & 0.789 \\
\hline \multicolumn{9}{|l|}{ Future component } \\
\hline Public speaking workshop & $\begin{array}{l}\text { Current } \\
\text { Past }\end{array}$ & $\begin{array}{l}7 \% \\
0\end{array}$ & $\begin{array}{l}3 \% \\
3 \%\end{array}$ & $\begin{array}{l}13 \% \\
19 \%\end{array}$ & $\begin{array}{l}33 \% \\
31 \%\end{array}$ & $\begin{array}{l}43 \% \\
47 \%\end{array}$ & $\begin{array}{l}4.03 \\
4.22\end{array}$ & 0.477 \\
\hline $\begin{array}{l}\text { Attendance at local dental society } \\
\text { leadership institute }\end{array}$ & $\begin{array}{l}\text { Current } \\
\text { Past }\end{array}$ & $\begin{array}{l}0 \\
0\end{array}$ & $\begin{array}{c}7 \% \\
0\end{array}$ & $\begin{array}{l}17 \% \\
13 \%\end{array}$ & $\begin{array}{l}27 \% \\
44 \%\end{array}$ & $\begin{array}{l}50 \% \\
44 \%\end{array}$ & $\begin{array}{l}4.20 \\
4.31\end{array}$ & 0.597 \\
\hline Dinner with dean & $\begin{array}{l}\text { Current } \\
\text { Past }\end{array}$ & $\begin{array}{l}7 \% \\
3 \%\end{array}$ & $\begin{array}{l}10 \% \\
3 \%\end{array}$ & $\begin{array}{l}24 \% \\
20 \%\end{array}$ & $\begin{array}{l}24 \% \\
40 \%\end{array}$ & $\begin{array}{l}35 \% \\
33 \%\end{array}$ & $\begin{array}{l}3.69 \\
3.97\end{array}$ & 0.352 \\
\hline $\begin{array}{l}\text { Recommendation to read } \\
\text { leadership-related book }\end{array}$ & $\begin{array}{l}\text { Current } \\
\text { Past }\end{array}$ & $\begin{array}{l}28 \% \\
13 \%\end{array}$ & $\begin{array}{l}17 \% \\
13 \%\end{array}$ & $\begin{array}{l}17 \% \\
25 \%\end{array}$ & $\begin{array}{l}10 \% \\
25 \%\end{array}$ & $\begin{array}{l}28 \% \\
25 \%\end{array}$ & $\begin{array}{l}2.93 \\
3.38\end{array}$ & 0.243 \\
\hline
\end{tabular}

Note: Full survey questions were worded as follows (top to bottom): "How much did these SPDL components prepare you for professional leadership roles?"; "SPDL helped me recognize career pathways I did not consider before (yes/no)"; and "How much would you like to see these components in SPDL?" Response options ranged from $1=$ not at all to $5=$ very much. Percentages may not total $100 \%$ because of rounding.

Table 3. Responses of dental students, SPDL alumni, and national dentists regarding their predoctoral education about leadership, by mean (SD)

Leadership Education

My predoctoral education prepared me well to:

Run an effective practice.

Interact and consult with colleagues in other practices.

Be a leader in my practice setting.

Be a leader in my community.

Be a leader in my state.

Be a leader at the national level.

Index: predoctoral leadership education (alpha=0.930)

My clinical experiences prepare(d) me well to:

Run an effective practice.

Interact and consult with colleagues in other practices.

Be a leader in my practice setting.

Index: clinical experiences preparing for dental practice (alpha=0.899)

My clinical experiences prepare(d) me well to:

Be a leader in my community.

Be a leader in my state.

Be a leader at the national level.

Index: clinical skills preparing for leadership roles (alpha=0.908)
SPDL National

Alumni Dentists p-value

$\begin{array}{llll}3.21(1.12) & 2.66(1.18) & 2.19(1.06) & <0.001 \\ 3.85(0.98) & 3.97(0.82) & 2.88(1.09) & <0.001 \\ 3.95(0.87) & 4.22(0.71) & 2.67(1.10) & <0.001 \\ 3.89(0.91) & 3.94(0.88) & 2.57(1.05) & <0.001 \\ 3.56(0.98) & 3.47(0.95) & 2.36(1.00) & <0.001 \\ 3.44(1.04) & 3.30(1.02) & 2.28(1.04) & <0.001 \\ 3.65(0.81) & 3.61(0.75) & 2.49(0.87) & <0.001\end{array}$

$3.74(0.96) \quad 3.81(1.26) \quad 3.81(1.04) \quad 0.716$

$\begin{array}{llll}4.01(0.88) & 4.50(0.57) & 4.02(0.88) & 0.007\end{array}$

$3.97(0.82) \quad 4.34(0.70) \quad 3.98(0.90) \quad 0.065$

$3.90(0.78) \quad 4.22(0.57) \quad 3.93(0.83) \quad 0.121$

$3.77(0.97) \quad 4.03(0.82) \quad 3.63(1.00) \quad 0.030$

$3.53(1.01) \quad 3.66(1.04) \quad 3.20(1.10) \quad<0.001$

$3.46(1.06) \quad 3.53(1.16) \quad 3.01(1.17) \quad<0.001$

$3.58(0.95) \quad 3.74(0.96) \quad 3.28(0.99) \quad<0.001$

Note: Response options ranged from $1=$ not at all to $5=$ very well. 
index "Clinical skills preparing for leadership roles" responses showed that the SPDL alumni had the most positive mean response and the general dentist group the least positive mean response.

A second set of comparisons of the three groups' responses was concerned with the degree to which these respondents thought that 20 activities were leadership indicators. The mean responses on four of the five indices computed to summarize these groups of activities differed significantly (Table 4). The SPDL alumni were most positive in considering recognition an indicator of leadership compared to dental students and general dentists (4.60 vs. 4.40 vs. $4.20 ; p<0.001)$. The same pattern of group differences was also found for the Community index, which assessed the degree of community involvement and its representation of leadership, and for the Academics index. Again, the SPDL alumni had the most positive and dentists the least positive mean responses for the Community index (4.40 vs. 4.04 vs. $3.81 ; p<0.001)$ and the Academics index (3.97 vs. 3.48 vs. 3.45 ; $\mathrm{p}<0.01)$. However, the current dental students had the most positive mean response to the questions of how much practice characteristics were part of leadership, and general dentists had the lowest response ( 3.43 vs. 2.84 vs. $2.72 ; p<0.001$ ). The final group of items was involvement with organized dentistry, such as holding local positions in organized dentistry, holding positions in the state, national positions, and being involved in dentistry-related politics and the legislature. Again, the SPDL alumni agreed overall more that being involved in organized dentistry was

Table 4. Responses of dental students, SPDL alumni, and national dentists regarding indicators of leadership, by mean (SD)

Indicator of Leadership

SPDL National

Recognition

Students

Alumni

Dentists

p-value

Being recognized in my community as an expert.

Being recognized by patients as an expert in the field of dentistry.

Being recognized by staff as an expert in the field of dentistry.

Being recognized by other dentists as an expert in the field of dentistry.

Being effective in managing staff.

Index: recognition (alpha $=0.839$ )

$4.31(0.71)$

$4.46(0.74)$

$4.43(0.73)$

$4.43(0.72)$

$4.40(0.63)$

Practice mindset

Owning a solo practice without associates.

Owning a solo practice with associates.

Being a partner in a group practice.

Being the first dentist in an area to use new instruments or techniques.

Index: practice mindset (alpha $=0.846$ )

$3.54(1.23)$

$3.43(1.13)$

$3.40(1.09)$

$3.35(1.10)$

$3.43(0.88)$

$4.50(0.67)$

$4.56(0.80)$

$4.00(0.96)$

$4.27(0.95)$

0.004

$4.59(0.76)$

$4.63(0.61)$

$4.68(0.48)$

$4.60(0.57)$

$4.35(0.86)$

$4.10(0.94)$

$4.06(0.88)$

$4.20(0.70)$

0.188

0.089

$<0.001$

$<0.001$

$<0.001$

Community

Volunteering dental services in the community.

Organizing community events with a dental focus.

Being a leader in the community outside of dentistry.

Index: community (alpha=0.735)

$4.21(0.88)$

$3.91(0.94)$

$3.99(0.99)$

$4.04(0.75)$

$2.41(1.21)$

(7.7.

$3.00(1.32)$

$3.03(1.28)$

$2.91(1.25)$

$2.84(1.03)$

$2.70(1.21)$

$<0.001$

$2.77(1.22)<0.001$

$2.64(1.13)<0.001$

$2.83(1.20)<0.001$

$2.72(0.98)<0.001$

Organized dentistry

Holding local positions in organized dentistry.

Holding positions in organized dentistry in my state.

$3.89(0.98)$

$3.82(1.01)$

$3.74(1.13)$

$3.63(1.05)$

Being involved in dentistry-related politics and legislature.

Index: organized dentistry (alpha=0.894)

$3.77(0.94)$

$4.44(0.76)$

$4.28(0.81)$

$3.86(0.76)$

$3.73(1.03)$

$4.47(0.62)$

$3.84(0.98)$

$4.40(0.57)$

$3.81(0.80)$

$<0.001$

0.002

0.001

$<0.001$

$4.16(0.77)$

$4.22(0.75)$

$4.19(0.78)$

$3.83(1.12)$

0.216

$4.13(0.83)$

$3.72(1.12)$

0.037

$3.64(1.23) \quad 0.028$

$4.17(0.72)$

$3.65(1.15)$

0.055

$3.71(1.08)$

0.045

Academics

Teaching other dental professionals.

Teaching students about dentistry.

$3.86(0.92)$

$4.45(0.77)$

$3.83(1.00)$

0.003

$3.90(0.96)$

$4.38(0.87)$

$3.87(0.99)$

0.017

Being involved in research.

Publishing articles in dental journals.

$3.12(1.21)$

$3.48(1.03)$

$3.11(1.11)$

$3.05(1.28)$

$3.55(1.12)$

$3.01(1.21)$

$3.48(0.91)$

0.010 
an indicator for leadership than the two other groups ( 4.17 vs. 3.77 vs. $3.71 ; p=0.045$ ). However, due to the Bonferroni correction that resulted in setting the accepted significance level to $\mathrm{p}<0.01$, those differences were not significant.

The last set of eight questions asked about the respondents' attitudes towards leadership (Table 5). The SPDL alumni and the current dental students had significantly more positive general leadership attitudes ("General views on leadership" index: 4.24 vs. 4.27 vs. $3.80 ; \mathrm{p}<0.001)$ and more positive "Views on practice efficiency" ( 4.61 vs. 4.53 vs. 4.36 ; $p<0.001$ ) than did the general dentists.

The final objective was to determine whether leadership-related educational/clinical experiences were related to the degree to which various activities were seen as indicators of leadership and the respondents' leadership-related attitudes. The respondents' age was significantly correlated with the quality of their leadership-related predoctoral education (Table 6). The older the respondents were, the less well they felt prepared by their predoctoral education $(r=-0.48 ; p<0.001)$ and their clinical experiences related to leadership roles $(\mathrm{r}=-0.13 ; \mathrm{p}<0.001)$. In addition, the older the respondents were, the less they considered recognition-related responses $(\mathrm{r}=-0.16$; $\mathrm{p}<0.001)$ and practice mindset-related responses $(\mathrm{r}=-0.26 ; \mathrm{p}<0.001)$ as indicators of leadership, and the more negative their attitudes concerning general views of leadership $(r=-0.26 ; p<0.001)$ and practice efficiencies $(r=-0.20 ; p<0.001)$. Overall, there was overwhelming evidence that the quality of predoctoral leadership education and the dental practice and leadership role-related clinical experiences were significantly correlated with leadership-related responses and attitudes. The only exception for the predoctoral education relationships and the clinical leadership-related role relationships was in the "Community involvement" domain. In addition, the dental practice-related clinical experiences were not correlated with the practice mindset index responses.

\section{Discussion}

Dental professionals need to take on leadership roles in addressing challenges in the U.S. health care system to ensure that dental experts and not policymakers from outside the field determine the future of the dental profession. ${ }^{2,3}$ Recruiting qualified students into academic careers makes use of many methods,${ }^{22-25}$ leadership efforts may be helpful in addressing that need as well. Exploring the effectiveness of various approaches to leadership-related efforts is therefore important.

One approach to dental leadership education can be to offer an elective program to interested students. The SPDL is one such program. Its evaluations by both current and past participants in this study were quite positive. Of specific interest is the finding that three out of four respondents agreed that the program helped them recognize career pathways

Table 5. Responses of dental students, SPDL alumni, and national dentists regarding their leadership-related attitudes, by mean (SD)

\begin{tabular}{|c|c|c|c|c|}
\hline Category & Students & $\begin{array}{l}\text { SPDL } \\
\text { Alumni }\end{array}$ & $\begin{array}{l}\text { National } \\
\text { Dentists }\end{array}$ & p-value \\
\hline \multicolumn{5}{|l|}{ General views on leadership } \\
\hline $\begin{array}{l}\text { How important is it for you that you are a good leader in your } \\
\text { profession? }\end{array}$ & $4.53(0.72)$ & $4.62(0.55)$ & $4.03(0.90)$ & $<0.0001$ \\
\hline How important is it for you that your peers think of you as a leader? & $4.35(0.88)$ & $4.34(0.94)$ & $3.67(1.05)$ & $<0.001$ \\
\hline $\begin{array}{l}\text { How important is it for you that dentists take a greater leadership } \\
\text { role? }\end{array}$ & $4.29(0.77)$ & $4.41(0.84)$ & $3.96(0.87)$ & $<0.001$ \\
\hline $\begin{array}{l}\text { How important is it that we have at least as many leaders in dentistry } \\
\text { as there are in other professions? }\end{array}$ & $3.98(1.04)$ & $4.09(0.86)$ & $3.96(0.98)$ & 0.751 \\
\hline How effective are you as a leader in your profession? & $4.21(0.75)$ & $3.67(0.88)$ & $3.35(0.98)$ & $<0.001$ \\
\hline Index: general views on leadership (alpha $=0.821$ ) & $4.27(0.61)$ & $4.24(0.58)$ & $3.80(0.73)$ & $<0.001$ \\
\hline \multicolumn{5}{|l|}{ Views on practice efficiency } \\
\hline How important is it that you a & $4.73(0.56)$ & $4.97(0.18)$ & $4.64(0.60)$ & 0.002 \\
\hline How important is it for you that your patients think of you as a leader? & $4.59(0.68)$ & $4.59(0.84)$ & $4.38(0.78)$ & 0.002 \\
\hline How effective are you as a leader in your own practice? & $4.48(0.61)$ & $4.06(0.63)$ & $4.05(0.70)$ & $<0.001$ \\
\hline Index: views on practice efficiency (alpha=0.606) & $4.61(0.48)$ & $4.53(0.39)$ & $4.36(0.51)$ & $<0.001$ \\
\hline
\end{tabular}

Note: Response options ranged from $1=$ not at all to $5=$ very much. 


\section{Table 6. Correlations between educational indices and leadership-related indices}

\begin{tabular}{|c|c|c|c|c|}
\hline \multirow[b]{2}{*}{ Index } & \multirow[b]{2}{*}{ Age } & \multirow[b]{2}{*}{$\begin{array}{c}\text { Predoctoral } \\
\text { Leadership Education }\end{array}$} & \multicolumn{2}{|c|}{ Clinical Experiences Preparing for } \\
\hline & & & $\begin{array}{c}\text { Dental } \\
\text { Practice }^{a}\end{array}$ & $\begin{array}{l}\text { Leadership } \\
\text { Roles }^{\mathrm{a}}\end{array}$ \\
\hline \multicolumn{5}{|l|}{ Education-related experiences indices ${ }^{a}$} \\
\hline Predoctoral leadership education & $-0.48^{* *}$ & - & $0.28^{* *}$ & $0.42^{* *}$ \\
\hline Clinical experiences: dental practice & -0.04 & $0.28^{* *}$ & - & $0.58^{* *}$ \\
\hline Clinical experiences: leadership roles & $-0.13^{* *}$ & $0.42^{* *}$ & $0.58^{* *}$ & - \\
\hline \multicolumn{5}{|l|}{ Indicators of leadership indices ${ }^{b}$} \\
\hline Recognition & $-0.16^{* *}$ & $0.17^{* *}$ & $0.25^{* *}$ & $0.23^{* *}$ \\
\hline Practice mindset & $-0.26^{* *}$ & $0.29 * *$ & 0.06 & $0.16^{* *}$ \\
\hline Community & -0.05 & 0.13 & $0.19 *$ & 0.14 \\
\hline Organized dentistry & -0.04 & $0.15^{* *}$ & $0.11 *$ & $0.21^{* *}$ \\
\hline Academics & -0.04 & $0.18^{* *}$ & $0.14^{* *}$ & $0.19^{* *}$ \\
\hline \multicolumn{5}{|l|}{ Leadership-related attitudes indices ${ }^{c}$} \\
\hline General views on leadership & $-0.26^{* *}$ & $0.41^{* *}$ & $0.27^{* *}$ & $0.45^{* *}$ \\
\hline Views on practice efficiency & $-0.20^{* *}$ & $0.21^{* *}$ & $0.31^{* *}$ & $0.29 * *$ \\
\hline \multicolumn{5}{|c|}{$\begin{array}{l}\text { aSee Table } 3 \text { for wording of items used to create these indices. } \\
\text { bSee Table } 4 \text { for wording of items used to create these indices. } \\
\text { "See Table } 5 \text { for wording of items used to create these indices. } \\
{ }^{*} p<0.01 ;{ }^{* *} p<0.001\end{array}$} \\
\hline
\end{tabular}

they had not considered before. SPDL alumni were also most positive in considering academic characteristics, specifically teaching and research, as indicators of leadership. These results point to the possibility of using leadership-related educational efforts to address faculty shortages.

In addition, the SPDL alumni in our study considered community involvement most strongly to be a leadership characteristic compared to the dental students and dentists. Since the year 2000, when the first U.S. surgeon general's report on oral health called attention to the fact that many patients from low-income and/or minority populations as well as patients with special health care needs face challenges with access to oral care, ${ }^{26}$ leadership efforts in dental education are needed to prepare future providers to address this problem. Leadership-related education such as the SPDL could play an important role in this context. It is also noteworthy that the SPDL alumni strongly considered holding positions in organized dentistry a leadership characteristic. In times of dramatic changes, organized dentistry needs dentists ready to take on responsibilities and leadership roles. ${ }^{1-3}$ The role of dental education in preparing future leaders should not be underestimated.

The data collected in our study showed that progress is being made to improve the quality of leadership-related education. The finding that the younger the respondents were, the more positively they evaluated their educational and clinical experiences related to leadership roles is quite encouraging, because these educational and clinical experiences were clearly related to respondents' leadershiprelated considerations and attitudes. Efforts of dental and dental hygiene educators need to continue.

This study had several limitations. First, the SPDL takes place at one specific dental school, and the current student respondents were all from this one institution. This fact might limit the generalizability of the dental students' responses because they know about the SPDL, and being in an environment with an elective leadership program might make leadership a more salient topic for all students. We recommend that future studies collect data from dental students at schools with different curricular approaches ${ }^{6}$ to allow for the exploration of how differing educational interventions affect leadership-related considerations, attitudes, and behavioral intentions. Second, the dental student data were mostly from students in the earlier years of the program. Future research should survey seniors close to graduation as well as alumni to assess the effectiveness of leadership-related educational efforts. Third, related to this second concern is the fact that the dental students had to report their expectations concerning how well their educational/clinical experiences had prepared them because they had not yet experienced the settings referred to in the questions. Fourth, the response rate 
of the general dentists was only $20 \%$. However, given the findings by Hardigan et al. concerning response rates to web-based (11\%) and postal/mailed surveys $(26 \%),{ }^{27}$ this response rate is not unusual because our mailed survey was very long, which is likely to reduce the response rate. Finally, it is possible that the $60 \%$ SPDL alumni response rate was of alumni with more positive evaluations of the SPDL. SPDL alumni who were less positive about this program may have been less likely to respond to the program director's recruitment email. This limitation should be kept in mind when interpreting the findings.

\section{Conclusion}

In this study, both current and past SPDL respondents evaluated this elective program very positively. The current dental students and alumni evaluated their predoctoral leadership-related experiences more positively than did the general dental practitioners. Overall, the younger the respondents, the more positively they evaluated their predoctoral leadership education and their clinical experiences related to leadership roles. The SPDL alumni considered professional recognition, community involvement, and academic involvement as more indicative of leadership than did the current students and general dentists. The current students and SPDL alumni also had more positive leadership-related attitudes than did the general dentists. These participants' leadership-related educational/clinical experiences were positively related to their perceptions of leadership characteristics and leadership-related attitudes.

\section{Acknowledgments}

We want to thank the ADA for providing us with their members' addresses and Michael Hyman, Yash Murthy, Charles Wenzel, and Benjamin Yoon for helping with the preparation of the data for analysis. This project was supported by the Major M. Ash Collegiate Professorship, Department of Periodontics and Oral Medicine, University of Michigan School of Dentistry. We want to thank the respondents for taking the time to respond to our survey.

\section{REFERENCES}

1. Taichman RS, Parkinson JW, Nelson BA, et al. Leadership training for oral health professionals: a call to action. J Dent Educ 2012;76(2):185-91.

2. Slavkin HC, Lawrence L. Incorporating leadership knowledge and skills into the dental education community. J Dent Educ 2007;71(6):708-12.
3. Sinkford JC. Introduction to the fourth ADEA international women's leadership conference proceedings. J Dent Educ 2011;75(3):S5-7.

4. Taichman LS, Taichman RS, Inglehart MR. Dentists' leadership-related educational experiences, attitudes, and past and current behavior. J Dent Educ 2014;78(6):876-85.

5. Victoroff KZ, Schneider K, Perry C. Leadership development for dental students: what do students think? J Dent Educ 2008;72(9):982-8.

6. Taichman RS, Parkinson JW. Where is leadership training being taught in U.S. dental schools? J Dent Educ 2012;76(6):713-20.

7. Forest AE, Taichman RS, Inglehart MR. Dentists' leadership-related perceptions, values, experiences, and behavior: results of a national survey. J Am Dent Assoc 2013;144(12):1397-405.

8. Connor JP, Troendle K. Perspectives on the dental school learning environment: Theory X, Theory Y, and situational leadership applied to dental education. J Dent Educ 2007;71(8):977-82.

9. Certosimo F. The servant leader: a higher calling for dental professionals. J Dent Educ 2009;73(9):1065-8.

10. Certosimo F. Leaders or managers: who will define a new vision for dental education? J Dent Educ 2010;74(5): 459-63.

11. Slavkin HC. Leadership for health care in the 21 st century: a personal perspective. J Healthcare Leadership 2010;2:35-41.

12. Willcocks S. Leadership theory: implications for developing dental surgeons in primary care? Br Dent J 2011;210(3):105-7.

13. Kalenderian EE, Taichman RS, Skoulas A, et al. Developing the next generation of leaders in oral health. J Dent Educ 2013;77(11):1508-14.

14. Taichman RS. Expanding the scholarship on leadership training in dental education. J Dent Educ 2014;78(6): $811-2$.

15. Victoroff KZ, Schneider K, Perry C. Tomorrow's leaders, starting today: a pilot leadership development program for dental students. J Dent Educ 2009;73(3):311-8.

16. Kalenderian E, Skoulas A, Timothe P, Friedland B. Integrating leadership into a practice management curriculum for dental students. J Dent Educ 2010;74(5):464-71.

17. Skoulas A, Kalenderian E. Leadership training for postdoctoral dental students. J Dent Educ 2012;76(9):1156-66.

18. Gironda MW, Bibb CA, Lefever K, et al. A program to recruit and mentor future academic dentists: successes and challenges. J Dent Educ 2013;77(3):292-9.

19. Haden NK, Ranney RR, Weinstein G, et al. Leadership development in dental education: report on the ADEA Leadership Institute, 2000-08. J Dent Educ 2010;74(3):331-51.

20. Taichman RS, Parkinson JW, Nelson BA, et al. Program design considerations for leadership training for dental and dental hygiene students. J Dent Educ 2012;76(2):192-9.

21. Taichman RS, Green TG, Polverini PJ. Creation of a scholars program in dental leadership (SPDL) for dental and dental hygiene students. J Dent Educ 2009;73(10): 1139-43.

22. Ballard RW, Hagan JL, Armbruster PC, Gallo JR III. Methods used by accredited dental specialty programs to advertise faculty positions: results of a national survey. $\mathrm{J}$ Dent Educ 2007;75(1):46-51. 
23. John V, Papageorge M, Jahangiri L, et al. Recruitment, development, and retention of dental faculty in a changing environment. J Dent Educ 2011;75(1):82-9.

24. Wanchek T, Cook BJ, Slapar F, Valachovic RW. Dental schools vacant budgeted faculty positions, academic year 2014-15. J Dent Educ 2016;80(8):1012-22.

25. Horvath Z, Albani SE, Wankiri-Hale C. Training future dentists for an academic career: a three-tiered model. J Dent Educ 2016;80(5):502-16.
26. Oral health in America: a report of the surgeon general. Rockville, MD: U.S. Department of Health and Human Services, National Institute of Dental and Craniofacial Research, National Institutes of Health, 2000.

27. Hardigan PC, Succar CT, Fleisher JM. An analysis of response rate and economic cost between mail and webbased surveys among practicing dentists: a randomized trial. J Community Health 2012;37:383-94. 